\title{
In vitro Mass Propagation from Shoot Tip Explants of Vernonia cinerea (L.) Less. - An Antioxidant, Anti- inflammatory Medicinal Plant
}

\section{Maharajan ${ }^{1}$, Abdul Bakrudeen Ali Ahmed*, Rosna Mat Taha, S. Jawahar'2, R. Ravi Paul² and M. Jayaseelan ${ }^{3}$}

Institute of Biological Sciences, Faculty of Science, University of Malaya, 50603, Kuala Lumpur, Malaysia

Key words: Vernonia cinerea, Mass propagation, Shoot tip explants, Antioxidant, Medicinal plant

\begin{abstract}
Plantlets were regenerated from the shoot tip explants of Vernonia cinerea (L.) Less. in MS supplimented with BA and $\mathrm{Kn}$. Maximum number of shoots in BA $(13.32 \mathrm{mg} / \mathrm{l})$ and roots in IBA $(7.38 \mathrm{mg} / \mathrm{l})$ developed. The rooted plantlets were successfully established in the field.
\end{abstract}

\section{Introduction}

Fatty oil, $\beta$-amyrin acetate, $\beta$-amyrin benzoate, $\beta$-sitosterol, stigmosterol, $\alpha$ spinnasterol (+)-lirioresinol B, stigmasterol, stigmasterol-3-O- $\beta$-D-glucoside, 4sulfo-benzocyclobutene compounds inducing NGF activity are extracted from Vernonia cinerea (L.) Less. (Asteraceae) (Zhu et al. 2008). It also contains medicinal properties for eczema, ringworm, elephantiasis, conjunctivitis, diarrhea, leucoderma, dysiria, skin diseases, leprosy, fevers, anti-cancer, antioxidant and anti-inflammatory (Kumar and Kuttan 2009). Nowadays, tissue culture techniques are actively employed biotechnological methods to improve the metabolites and medicinal plants in a large scale. Here, to develop an effective in vitro method for plant regeneration of $V$. cinerea and the propagated plants were successfully established in field conditions.

*Author for correspondence. <bakru24@yahoo.co.in>.1Department of Botany, School of Life Sciences, Bharathiar University, Coimbatore, Tamil Nadu, India. ${ }^{2}$ Department of Biotechnology, Bharath College of Science and Management, Thanjavur, Tamil Nadu, India. ${ }^{3}$ Department of Biotechnology, Ponnaiyah Ramajayam College, Tamil Nadu, India. 


\section{Materials and Methods}

Shoot tips of Vernonia cinerea (L.) Less. were collected from field grown plants (Fig. 1a). The explants were washed with $70 \%$ ethanol, $0.1 \% \mathrm{HgCl}_{2}(\mathrm{w} / \mathrm{v})$ for 3 min and rinsed with sterile distilled water for three to four times. Explants were cultured on MS containing 3.0\% sucrose (w/v) and BA $(2.22$ to $22.20 \mu \mathrm{M} / \mathrm{l})$ and $\mathrm{Kn}(2.32$ to $23.20 \mu \mathrm{M} / \mathrm{l})$ for multiplication of plants with optimum $\mathrm{pH}(5.8 \pm 1)$, light intensity $\left(85 \mu \mathrm{mol} / \mathrm{m}^{2} / \mathrm{s}^{1}\right), 16 \mathrm{~h}$. The regenerated shoots were kept into the rooting medium with IBA $(2.46$ to $14 \mu \mathrm{M} / \mathrm{l})$. Plantlets were transferred to plastic cups containing sterile soil, sand, vermiculite $(1: 1: 1)$, and then transferred to field. All the treatments were statistically analyzed by DMRT) (Gomez and Gomez 1976).

\section{Results and Discussion}

Table 1 shows the successful results. Shoot tips were cultured on MS supplemented with different concentrations of BA $(2.22$ to $22.20 \mu \mathrm{M} / \mathrm{l})$ and $\mathrm{Kn}$ ( 2.32 to $23.20 \mu \mathrm{M} / \mathrm{l}$ ). Higher number of multiple shoot induction was observed in 30 days and significantly higher in BA than Kn (Fig. 1b, c). The maximum number of multiple shoots (148.2/shoot tip) was obtained in MS with BA 13.32 $\mu \mathrm{M} / 1$ (Table 1; Fig. 1d, e). Similar results were reported in Emblica offcinalis (Verma and Kant 1996) and Withania sominifera (Deka et al. 1999).

Table 1. Effect of $\mathrm{Kn}$ and BA on multiple shoot induction from shoot tip explants of Vernonia cinerea (L.) Less.

\begin{tabular}{|c|c|c|c|}
\hline $\begin{array}{l}\text { Plant growth } \\
\text { regulators }(\mu \mathrm{M} / \mathrm{l})\end{array}$ & $\begin{array}{c}\text { Regenerating } \\
\text { shoots (\%) }\end{array}$ & $\begin{array}{c}\text { No. of shoots/ } \\
\text { explants }\end{array}$ & $\begin{array}{c}\text { Shoot } \\
\text { length }(\mathrm{cm})\end{array}$ \\
\hline \multicolumn{4}{|l|}{$\mathrm{Kn}$} \\
\hline 2.32 & $33.8 \pm 3.7^{f}$ & $39.0 \pm 3.6^{f}$ & $0.8 \pm 0.2^{\mathrm{f}}$ \\
\hline 4.64 & $40.3 \pm 2.5^{\mathrm{e}}$ & $69.0 \pm 3.6^{\mathrm{de}}$ & $2.6 \pm 0.5^{\mathrm{de}}$ \\
\hline 9.28 & $48.0 \pm 2.6^{c}$ & $83.0 \pm 7.2^{b}$ & $4.0 \pm 1.0^{c}$ \\
\hline 13.92 & $69.0 \pm 1.0^{\mathrm{a}}$ & $131.6 \pm 10.4^{\mathrm{a}}$ & $6.5 \pm 0.5^{\mathrm{a}}$ \\
\hline 18.56 & $62.6 \pm 2.5^{b}$ & $81.0 \pm 3.6^{\mathrm{bc}}$ & $4.6 \pm 0.5^{b}$ \\
\hline 23.20 & $46.6 \pm 1.5^{\mathrm{cd}}$ & $71.3 \pm 3.2^{\mathrm{d}}$ & $3.0 \pm 1.0^{\mathrm{d}}$ \\
\hline \multicolumn{4}{|l|}{ BA } \\
\hline 2.22 & $38.1 \pm 0.7^{f}$ & $46.6 \pm 1.5^{\mathrm{f}}$ & $1.6 \pm 0.5^{f}$ \\
\hline 4.44 & $46.3 \pm 1.5^{\mathrm{e}}$ & $70.0 \pm 1.0^{\mathrm{e}}$ & $3.3 \pm 0.5^{\mathrm{de}}$ \\
\hline 8.88 & $57.3 \pm 2.5^{b c}$ & $101.6 \pm 7.6^{\mathrm{b}}$ & $5.6 \pm 0.5^{c}$ \\
\hline 13.32 & $73.0 \pm 2.6^{\mathrm{a}}$ & $148.3 \pm 2.8^{\mathrm{a}}$ & $9.0 \pm 1.0^{\mathrm{a}}$ \\
\hline 17.76 & $59.6 \pm 2.0^{\mathrm{b}}$ & $91.6 \pm 5.6^{c}$ & $6.3 \pm 0.5^{b}$ \\
\hline 22.20 & $52.0 \pm 2.0^{\mathrm{d}}$ & $88.3 \pm 7.6^{\mathrm{cd}}$ & $4.0 \pm 1.0^{\mathrm{d}}$ \\
\hline
\end{tabular}

Values are mean of 30 replicates per treatment and repeated thrice. Values with the same superscript are not significantly different at $5 \%$ probability according to DMRT. 
Patnaik and Chand (1996) reported BA was superior for multiple shoot induction than other cytokinins in shoot tip explants. Beena et al. (2003) reported that the Kn did not support the proliferation of multiple shoots in Ceropegia candelabrum, but the $\mathrm{Kn}$ also favoured for high rate of multiple shoot induction.

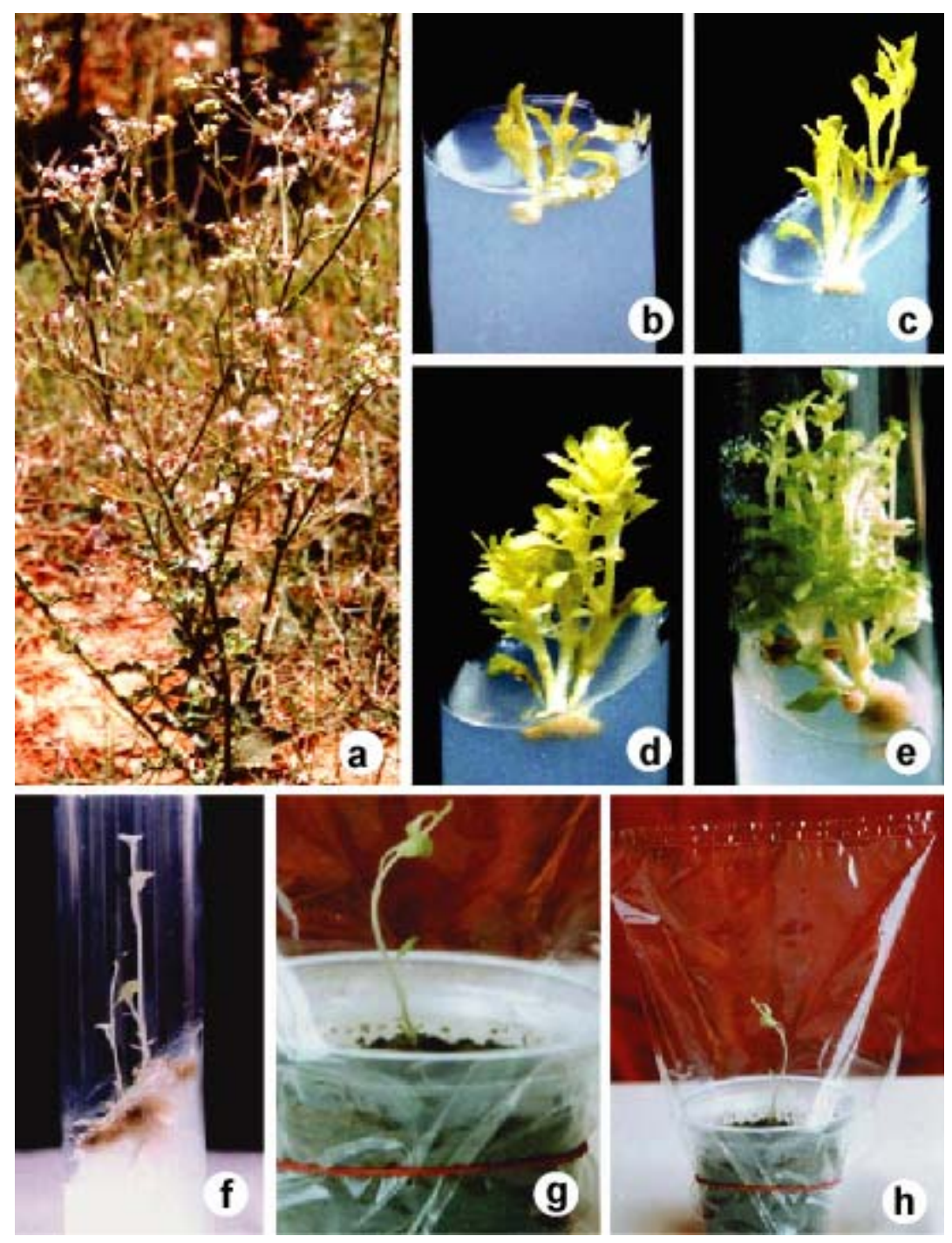

Fig. 1. a. Habitat, b-c. Multiple shoot initiation, d-e. Multiple shoots, f. Rooting and $g$, h. Hardening.

The well developed shoots were transferred for root induction in medium containing IBA (2.46 to $14.76 \mu \mathrm{M} / \mathrm{l})$ and IAA $(2.85$ to $17.13 \mu \mathrm{M} / \mathrm{l})$ at 25 days. Maximum number of roots per shoot was observed in IBA $7.38 \mu \mathrm{M} / 1$ (Table 2; Fig. 1f), whereas, the higher level of IBA showed low frequency root induction. 
Patnaik and Chand (1996) suggested that the best rooting medium contained IBA. Well-developed rooted plantlets were transferred to plastic cups and covered with polythene and maintained in tissue culture conditions (Fig. 1g, h). Finally, the developed plantlets were kept in greenhouse, and then transferred to field. The survival rate was 55\%.

Table 2. Effect of IAA and IBA on root induction from shoot tips derived plantlets of Vernonia cinerea (L.) Less.

\begin{tabular}{cccc}
\hline $\begin{array}{c}\text { Plant growth } \\
\text { regulators }(\mu \mathrm{M} / \mathrm{l})\end{array}$ & $\begin{array}{c}\text { Root formation } \\
(\%)\end{array}$ & $\begin{array}{c}\text { Average No. of } \\
\text { roots/shoot }\end{array}$ \\
\hline IAA & & & \\
& 2.85 & $32.0 \pm 4.89^{\mathrm{d}}$ & $1.6 \pm 0.47^{\mathrm{e}}$ \\
& 5.71 & $54.0 \pm 1.63^{\mathrm{b}}$ & $2.9 \pm 0.34^{\mathrm{c}}$ \\
& 8.56 & $62.3 \pm 2.05^{\mathrm{a}}$ & $6.0 \pm 0.81^{\mathrm{a}}$ \\
& 11.42 & $50.0 \pm 1.23^{\mathrm{bc}}$ & $4.3 \pm 0.47^{\mathrm{b}}$ \\
& 17.13 & $30.0 \pm 4.89^{\mathrm{cd}}$ & $2.3 \pm 0.37^{\mathrm{cd}}$ \\
IBA & & & \\
& 2.46 & & \\
& 4.92 & $32.0 \pm 4.89^{\mathrm{d}}$ & $1.6 \pm 0.47^{\mathrm{e}}$ \\
& 7.38 & $56.6 \pm 2.62^{\mathrm{bc}}$ & $3.3 \pm 0.27^{\mathrm{c}}$ \\
& 9.84 & $70.6 \pm 4.08^{\mathrm{a}}$ & $8.0 \pm 0.81^{\mathrm{a}}$ \\
& 14.76 & $62.3 \pm 2.05^{\mathrm{b}}$ & $6.6 \pm 1.24^{\mathrm{b}}$ \\
& & $30.0 \pm 4.89^{\mathrm{de}}$ & $3.0 \pm 0.81^{\mathrm{cd}}$ \\
\hline
\end{tabular}

Values are mean of 30 replicates per treatment and repeated thrice. Values with the same superscript are not significantly different at $5 \%$ probability according to DMRT.

In conclusion, the micropropagation protocol was established from shoot tip explants of $V$. cinerea. The rehabilitation micropropagation development total process was completed in 60 days. This efficient micropropagation protocol will be useful to conservation, and in the improvement of $V$. cinerea using genetic transformation.

\section{References}

Beena MR, Martin KP, Kirti PB and Hariharan M (2003) Rapid in vitro propagation of medicinally important Ceropegia candelabrum. Plant Cell Tiss. Org. Cult. 72: 285-289.

Deka AC, Kalita ML and Baruah A (1999) Micropropagation of a potent herbal medicinal plant, Withania sominiferea. Environ. Ecology. 17: 596.

Gomez KA and Gomez AA (1976) Statistical procedures for agricultural research with emphasis on rice. International Rice Research Institute. Los Banos, Philippines, p. 264.

Kumar P and Kuttan G (2009) Vernonia cinerea (L.) Less. scavenges free radicals and regulates nitric oxide and proinflammatory cytokines profile in carrgeenan induced paw edema model. Immunopharma. Immnotoxicol. 31: 94-102. 
Patnaik S and Chand PK (1996) In vitro propagation of the medicinal herbs Ocimum americanum L.Syh. Ocimum sims (Hoary basil) and Ocimum sanctum L. (Holy basil). Plant Cell Reports 15: 846-850.

Verma B and Kant U (1996) Micropropagation of Embilica officinale Gaertz through mature nodal explant. J. Phytal. Res. 9: 107-109.

Zhu HX, Tang YP, Pan LM and Min ZD (2008) Studies on bioactive constituents of whole herbs of Vernonia cinerea. Zhongguo Zhongyao Zazhi. 33: 1986-1988. 